\title{
Evaluation of immunoresponses and cytotoxicity from skin exposure to metallic nanoparticles
}

This article was published in the following Dove Press journal:

International Journal of Nanomedicine

\author{
Menglei Wang' \\ Xuan Lai $^{2}$ \\ Longquan Shao ${ }^{2}$ \\ $\mathrm{Li} \mathrm{Li'}$
}

'Department of Dermatology, Nanfang Hospital, Southern Medical University, Guangzhou, Guangdong, 5 I05 I5, China; ${ }^{2}$ Department of Stomatology, Nanfang Hospital, Southern Medical University, Guangzhou, Guangdong,

5I05I5, China
Correspondence: Li Li

Department of Dermatology, Nanfang Hospital, Southern Medical University,

1838 Guangzhou North Avenue, Baiyun

Qu, Guangzhou, 5105I5, China

Tel +86 I 33I 8827908

Email13318827908@|26.com

\begin{abstract}
Nanotechnology is an interdisciplinary science that has developed rapidly in recent years. Metallic nanoparticles (NPs) are increasingly utilized in dermatology and cosmetology, because of their unique properties. However, skin exposure to NPs raises concerns regarding their transdermal toxicity. The tight junctions of epithelial cells form the skin barrier, which protects the host against external substances. Recent studies have found that NPs can pass through the skin barrier into deeper layers, indicating that skin exposure is a means for NPs to enter the body. The distribution and interaction of NPs with skin cells may cause toxic side effects. In this review, possible penetration pathways and related toxicity mechanisms are discussed. The limitations of current experimental methods on the penetration and toxic effects of metallic NPs are also described. This review contributes to a better understanding of the risks of topically applied metallic NPs and provides a foundation for future studies.
\end{abstract}

Keywords: metallic nanoparticles, transdermal penetration, toxicity

\section{Introduction}

Nanomaterials are different types of materials in which at least one dimension is on the nanometer scale. In principle, a single unit of a nanomaterial is $1-100 \mathrm{~nm}$ in size. This size is equivalent to the scale of $10-100$ closely packed atoms. ${ }^{1}$ The ratio of surface atomic numbers and the surface:volume ratio are increased due to this small scale. A larger surface:volume ratio gives nanomaterials unique physical and chemical properties relative to other materials, including enhanced hardness, plasticity, conductivity, diffusivity, optical properties, and chemical reactivity. ${ }^{2,3}$ The concept of nanotechnology was first mentioned by Richard Feynman in 1959. After 30 years of rapid development, nanotechnology has become a major technology. More than 1,800 kinds of nanotechnology-based products have been applied in various areas, such as in the machinery and textile industries, cosmetics, and medicine. ${ }^{4}$

Metallic (metal or metal oxide) nanoparticles (NPs) are increasingly used in derma-

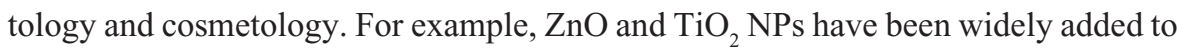
sunscreens since the 1980 s to confer better ultraviolet (UV) protection than traditional inorganic sunscreens. ${ }^{5}$ Due to enhanced antibacterial activity and reduced side effects, AgNP-based products, such as detergent, bandages, catheters, antibacterial sprays, shoes, and food-storage containers, are used widely in our daily lives. ${ }^{6} \mathrm{SiO}_{2} \mathrm{NPs}$ are used in a number of fields like coatings, rubber, ceramics, and a variety of cosmetics as antisetting and thickening agents, but they tend to evaporate because of the low density. ${ }^{7}$ $\mathrm{Fe}_{3} \mathrm{O}_{4} \mathrm{NP}$-based cancer therapy is increasingly used in the biomedical field, because such nanoscale NPs can easily enter tumor cells and lead to apoptosis or necrosis. ${ }^{8}$ Metallic NPs, such as AuNPs and CuNPs, were introduced to the dermatology field 
for the prevention and treatment of infections and wound healing, because of their excellent antibacterial properties. ${ }^{9}$ All these aspects have greatly increased skin exposure to metallic NPs. ${ }^{10}$

The skin is the largest organ of the human body, with a surface area of 1.5-2 $\mathrm{m}^{2}$, and is composed of the epidermis and dermis. The stratum corneum (SC), sebum membrane, lipids, and tight intercellular junctions between keratinocytes in the epidermis form a physical barrier to protect the host against toxins and pathogens. Metallic NPs can pass through not only the SC of healthy skin but also hair follicles and sebaceous glands. ${ }^{11}$ As a matter of fact, the skin barrier is not always intact. It can be altered in many ways, such as by mechanical damage, chemical irritants, UV exposure, inflammatory infiltrates, and microbial colonization. ${ }^{12}$ For example, atopic dermatitis (AD) and psoriasis are common inflammatory skin disorders characterized by skin-barrier dysfunction. Disturbances in skin integrity allow NPs to penetrate deeper dermal layers. In fact, reports have demonstrated NP penetration through skin cells in healthy and damaged skin by transcellular and follicular penetration pathways. ${ }^{13}$

While NPs offer advantages, their disadvantages include efficient penetration, poor elimination, and tissue accumulation, in addition to toxicity. Indeed, increasing skin exposure (and ultimately systemic absorption) raises serious safety concerns. Once NPs infiltrate the skin, they can exhibit various toxic effects, such as oxidative stress, cell apoptosis, mitochondrial dysfunction, and cytomembrane and DNA damage. ${ }^{14}$ Some in vitro data have demonstrated their toxicity to human epidermal keratinocytes and hair-follicle stem cells. ${ }^{15,16}$ Additionally, the metallic ions released by metallic NPs may cause sensitization and irritation following exposure. However, despite intensive studies on transdermal toxicity, the penetration mechanisms of NPs remain largely unexplored. It is also unknown whether their toxic effects are related to unique penetration pathways. Another question is whether new injury mechanisms exist in the penetration of damaged skin. Even if no new mechanisms exist, what are the toxicity differences between intact and damaged skin?

This review aims to discuss the possible routes of metallic NP penetration into the skin and provide a detailed introduction to recent advances in explorations of their toxic effects and related mechanisms. Finally, we emphasize the limitations of current research methods and propose hypotheses for better understanding of transdermal risks in future studies.

\section{Skin absorption of metallic NPs}

The skin is a barrier that protects an organism from environmental allergens, chemicals, and harmful materials. This unique barrier is composed of the epidermis, dermis, hypodermis, and many appendages, such as hair follicles, sweat glands, and sebaceous glands. The epidermis is important from a barrier perspective. Skin-barrier function is attributed mainly to the SC, the outermost layer of the epidermis. The ability of metallic NPs to overcome this skin barrier and penetrate deep-skin layers is a subject of debate. ${ }^{17}$

In the last decade, an increasing number of studies have focused on skin penetration by metallic NPs; however, different conclusions have been reported. An earlier mainstream hypothesis suggested that metallic NPs did not pass through the skin barrier. This hypothesis was revised with improved techniques to analyze NPs inside the skin. An increasing number of research articles have reported skin penetration by metallic NPs. Statistically, the frequency of these articles rose from $38 \%$ in 2008 to $67 \%$ in 2010 . However, this increase was possibly due to differences in experimental protocols and approaches to enhance skin penetration (Table 1). ${ }^{18-28}$

Such factors as size, shape, charge, formation, and surface modification can critically influence the skin absorption of metallic NPs. In general, smaller NPs tend to be able to move in and out of cells. It has been presumed that NPs $<4 \mathrm{~nm}$ in size can penetrate intact skin, NPs 4-20 nm can probably penetrate both intact and damaged skin, and NPs 21-45 nm can penetrate only damaged skin, whereas NPs $>45 \mathrm{~nm}$ cannot penetrate intact or damaged skin. ${ }^{10}$ Other data have indicated that positively charged NPs are more likely to be ingested by skin cells. AuNPs with terminal amine penetrated the skin at two to six times in amount of NPs with a carboxylic group. ${ }^{29}$ Indeed, the diffusion performance of metallic NPs also relies on formulation composition. The semisolid formation of $\mathrm{Fe}_{3} \mathrm{O}_{4}$ NPs can influence NP penetration in comparison to aqueous suspensions. $\mathrm{Fe}_{3} \mathrm{O}_{4}$ NPs loaded in Cetomacrogol cream allow high permeability, while cold-cream formulations prevented their penetration by aggregating the NPs on the skin membrane. ${ }^{30}$ Tak et al ${ }^{13}$ suggested that rod-shaped AgNPs penetrated deep layers of the SC more easily compared to triangular or spherical AgNPs. In mice, the highest silver concentration in blood resulted in topical application of rodshaped AgNPs (108 ng/mL), while silver concentrations in blood that had penetrated from triangles or spheres were 39 and $50 \mathrm{ng} / \mathrm{mL}$, respectively. However, not all metallic NPs are systemically absorbed by skin exposure. There were no significant differences in titanium concentrations in primary organs of mice after topically applied $\mathrm{TiO}_{2}$ NPs for 4 weeks. ${ }^{20}$

\section{Possible pathways through the skin barrier}

Based on toxicity studies, NPs must be able to reach living cells under the SC. Despite their limitations, previous 
Table I Skin absorption of metallic NPs

\begin{tabular}{|c|c|c|c|c|c|}
\hline & Species & $\begin{array}{l}\text { Study } \\
\text { duration }\end{array}$ & $\begin{array}{l}\text { Analysis } \\
\text { method }\end{array}$ & Observation & Reference \\
\hline $\mathrm{ZnO} N P s$ & Human & 2,4 hours & $\begin{array}{l}\text { ZnO NPs and } \\
\text { NAD(P)H signals } \\
\text { quantified by } \\
\text { TCSPC-FLIM }\end{array}$ & $\begin{array}{l}\text { No } \mathrm{ZnO} \text {-NP penetration detected in human skin after } \\
2 \text { and } 4 \text { hours' treatment; free NAD(P)H signal significantly } \\
\text { increased in tape-stripped viable epidermis treated for } \\
4 \text { hours with ZnO-NP compared to vehicle control }\end{array}$ & 19 \\
\hline $\mathrm{TiO}_{2} \mathrm{NPs}$ & Hairless rat & $\begin{array}{l}2,4 \text {, and } \\
8 \text { weeks }\end{array}$ & $\begin{array}{l}\text { Histopathological, } \\
\text { TEM, EDS }\end{array}$ & $\begin{array}{l}\text { Particles located only in stratum corneum layer of epidermis } \\
\text { and follicular epithelium histopathologically; TEM and EDS } \\
\text { analysis failed to show } \mathrm{TiO}_{2} \mathrm{NPs} \text { in viable skin areas }\end{array}$ & 20 \\
\hline $\mathrm{TiO}_{2} \mathrm{NPs}$ & Porcine back skin & $8,24,48$ hours & $\begin{array}{l}\text { PIXE, RBS, STIM, } \\
\text { SEI }\end{array}$ & $\begin{array}{l}\mathrm{TiO}_{2} \text { NPs penetrated SC into SG but not SS within } 8 \text { hours; } \\
\text { NPs not detected in hair follicles }\end{array}$ & 21 \\
\hline $\begin{array}{l}\mathrm{TiO}_{2} \mathrm{NPs} \text { and } \\
\mathrm{ZnO} \mathrm{NPs}\end{array}$ & Human & 2, 48 hours & $\begin{array}{l}\text { Nuclear } \\
\text { microscopy, PIXE }\end{array}$ & $\begin{array}{l}\text { NPs observed only in the } 70 \%-90 \% \text { depth of SC and } \\
\text { openings of follicles }\end{array}$ & 22 \\
\hline AuNPs & Human & 2 hours & $\begin{array}{l}\text { Multiphoton } \\
\text { microscopy }\end{array}$ & $\begin{array}{l}\text { AuNPs detected up to } 14 \mu \mathrm{m} \text { deep in human skin, whereas } \\
\text { a wide range of detectable depths }(20-100 \mu \mathrm{m}) \text { observed in } \\
\text { reconstructed skin }\end{array}$ & 23 \\
\hline $\mathrm{AgNPs}$ & Porcine ear skin & 24 hours & $\begin{array}{l}\text { TPT-FLIM, CRM, } \\
\text { SERS }\end{array}$ & $\begin{array}{l}\text { TPT-FLIM, CRM, SERS showed depths of } 12-14 \text {, } \\
11.1 \pm 2.1 \text {, and } 15.6 \pm 8.3 \mu \mathrm{m} \text {, respectively }\end{array}$ & 24 \\
\hline AgNPs & Human & 4-6 days & $\begin{array}{l}\text { Histopathological, } \\
\text { SEM, XRD }\end{array}$ & $\begin{array}{l}\text { A limited number of NPs noted histopathologically; metallic } \\
\text { particles seen within the dermis by SEM; XRD confirmed } \\
\text { these were AgNPs }\end{array}$ & 25 \\
\hline AuNPs & Human & $\begin{array}{l}0.5,2,6, \text { and } \\
24 \text { hours }\end{array}$ & $\begin{array}{l}\text { Franz method, } \\
\text { multiphoton } \\
\text { microscopy }\end{array}$ & $\begin{array}{l}\text { AuNPs penetrated SC into deeper skin layers after } 24 \text { hours' } \\
\text { skin exposure }\end{array}$ & 26 \\
\hline CoNPs & $\begin{array}{l}\text { Human intact and } \\
\text { abraded skin }\end{array}$ & $\begin{array}{l}2,4,8,16 \text {, and } \\
24 \text { hours }\end{array}$ & $\begin{array}{l}\text { Franz method, } \\
\text { ICP-AES }\end{array}$ & $\begin{array}{l}\text { NPs able to penetrate human skin in an in vitro cell-diffusion } \\
\text { system; cobalt concentration in damaged skin significantly } \\
\text { greater than in intact skin }\end{array}$ & 27 \\
\hline NiNPs & $\begin{array}{l}\text { Human intact and } \\
\text { needle-abraded } \\
\text { human skin }\end{array}$ & $\begin{array}{l}4,8,16, \text { and } \\
24 \text { hours }\end{array}$ & $\begin{array}{l}\text { Franz method, } \\
\text { ICP-AES }\end{array}$ & $\begin{array}{l}\text { NiNPs caused increase in nickel content into skin and } \\
\text { significant permeation flux through skin in vitro, higher when } \\
\text { damaged-skin protocol used }\end{array}$ & 28 \\
\hline
\end{tabular}

Abbreviations: TCSPC, time-correlated single-photon counting; FLIM, fluorescence-lifetime imaging microscopy; TEM, transmission electron microscopy; EDS, energydispersive X-ray spectroscopy; SG, stratum granulosum; SS, stratum spinosum; PIXE, particle-induced X-ray emission; RBS, Rutherford back-scattering; STIM, scanning transmission ion microscopy; SEl, secondary electron imaging; TPT, two-photon tomography; CRM, confocal Raman microscopy; SERS, surface-enhanced Raman scattering; $\mathrm{XRD}$, X-ray diffusion; ICP-AES, inductively coupled plasma-atomic-emission spectroscopy; NPs, nanoparticles.

skin-permeation investigations have revealed the main skin-delivery routes of transdermal NPs, which are shown in Figure $1 .{ }^{31}$ The intercellular route penetrates the SC through intercellular spaces between keratinocytes on intact skin. Hair follicles are open to the skin surface and freely accessible from the outside, allowing NPs to lodge within them. Even though hair follicles occupy only $0.1 \%$ of the skin surface, this follicular route plays a chief role in skin penetration. ${ }^{13}$

\section{Lipophilic infiltration}

The structure of the SC in the epidermis is characterized as a lipoid "brick wall". Highly arranged keratinocytes hinder efficient substrate transport, and the lipid matrix is embedded in the "brick wall". The intercellular route is a tortuous pathway: NPs diffuse through intercellular lipids. Because the tissue below the $\mathrm{SC}$ is an aqueous environment, these lipid molecules can easily distribute in the SC. Lee et al showed that $\mathrm{Fe}_{3} \mathrm{O}_{4}$ NPs penetrated superficial skin incisions by intercellular and intracellular mechanisms. However, this penetration occurred only near the incision. Beyond a certain distribution distance, NPs were viable only in intercellular spaces. ${ }^{32}$ Intercellular penetration depends mainly on lipids in intercellular spaces, which are arranged in a head-tohead and tail-to-tail manner. The two tops of the lipids form hydrophilic and aqueous pores, enabling the penetration of hydrophilic and hydrophilic penetrants, respectively. Transmission electron microscopy (TEM) examination has been used to trace the localization of NPs inside the skin, and most NPs were detected in the intercellular lipids of the SC layer. ${ }^{33}$ Furthermore, the surface hydrophobicity of NPs was an important factor favoring skin penetration. Hydrophilic AuNPs did not penetrate the deep skin layer. In contrast, AuNPs with modified hydrophobic surfaces were distributed in deeper layers, indicating that AuNPs are expected to penetrate through intercellular lipoid channels. ${ }^{29}$

\section{Follicular route}

Recently, the follicular route has been considered an efficient penetration route for topically applied NPs. Hair follicles are surrounded by capillaries and sebaceous glands. 


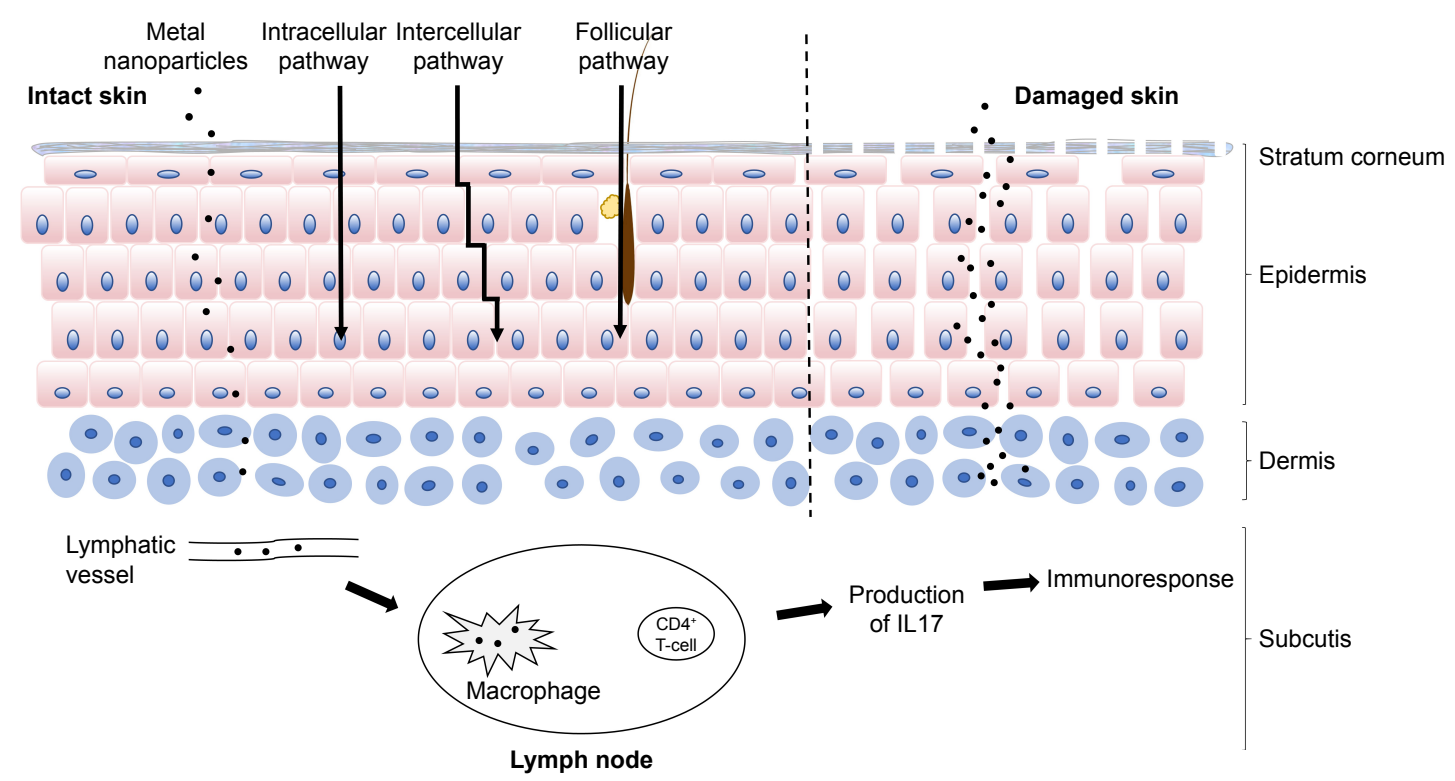

Figure I Skin penetration of metal NPs.

Notes: Three main possible skin-penetration pathways are illustrated: the intracellular pathway, intercellular pathway, and follicular pathway. Metal NPs may penetrate the stratum corneum in healthy skin. In damaged skin, more NPs may penetrate the epidermis and dermis. They may move to the lymph modes and be engulfed by macrophages. During penetration, metal NPs release metal ions, which induce metal ion-specific CD4+ T-cell and ILI7-mediated immunoreactions.

Abbreviation: NPs, nanoparticles.

Pilosebaceous units are the key components of hair follicles, and can act as reservoirs for NP lodgment. Generally, these deposited NPs cannot be eliminated easily by shower gels or natural skin metabolism, but they can sometimes be removed by hair growth and sebum secretion. ${ }^{13}$ NPs stored in hair follicles can be continuously absorbed into deep-skin layers. However, the underlying mechanism is still being investigated. In fact, a tight-junction barrier exists in hair follicles. This barrier structure has been investigated by detecting the expression and location of tight-junction proteins, and the barrier function examined using a biotin-labeled extracellular tracer molecule. The results showed that functional tight junctions formed a follicular barrier from the infundibular to suprabulbar region, which indicates that two barriers exist in the upper infundibulum: the SC and follicular tight junctions. However, only the follicular barrier exists from the isthmus to suprabulbar region, and no barrier was detected in the bulbar region. The bulbar region may be the main channel of the follicular route. ${ }^{34}$

Many researchers have attempted to investigate the follicular penetration of metallic NPs. Senzui et a ${ }^{35}$ observed $\mathrm{TiO}_{2}$ NPs on intact and hair-removed skin. The results showed that hair removal promoted skin penetration, and scanning electron microscopy (SEM)-energy-dispersive X-ray spectroscopy images showed that $\mathrm{TiO}_{2}$ NPs were detected in empty hair follicles. However, follicular penetration seems to depend on hair-follicle type and density and the physicochemical properties of topically applied NPs. A study found that hydrophobic AuNPs had enhanced penetration into hair follicles. As AuNPs are distributed into hair follicles, their hydrophilic substances may be found in the sebaceous gland system. ${ }^{36}$ It is understandable that higher follicular density results in a higher absorption rate, which was confirmed several decades ago ${ }^{37}$ In addition, each hair follicle has a growth cycle. Inactive hair follicles have neither hair growth nor sebum flow, which may provide weakened absorption ability.

However, due to physiological and anatomical differences, follicular penetration studies in both in vivo and in vitro models may not completely simulate human hair-follicle exposure. Hair removal is one of the simplest approaches, but it creates a risk of destroying normal structures and barrier functions. After hair removal, penetration may be influenced by contractive elastic fibers, which surround the hair follicles and reduce the follicular reservoir. A selective hair-follicle-closing technique was developed to investigate follicular and nonfollicular penetration. A special wax mixture was applied to close hair follicles. This method preserved follicular structures and inhibited the penetration process.$^{38}$ Future studies should consider these factors when interpreting follicular penetration.

\section{Percutaneous absorption in damaged skin}

The SC provides an efficient barrier against exogenous materials. However, the barrier is not always impervious, 
because the skin is assaulted by UV exposure, mechanical damage, microbial pathogens, and chemical irritation..$^{39}$ In skin diseases, skin structure and function can be disrupted. In inflammatory skin diseases, such as psoriasis and $\mathrm{AD}$, the differentiation of keratinocytes, composition of lipids, and function of tight junctions are affected by pathogenic processes. People with intact skin barriers and those with dysfunctional skin barriers could be exposed to metallic NPs in many situations. Studies have demonstrated that penetration may be enhanced in damaged skin (Figure 1).40-42 Transdermally applied NiNPs cause penetration into both intact and damaged skin, but the penetration is significantly deeper and of higher quantity in damaged skin. ${ }^{28} \mathrm{An}$ in vitro cell-diffusion system was used to explore the skin absorption of CoNPs in full-thickness human skin and abraded skin. Higher cobalt content was found in the receiving fluid when damaged skin was used, and inductively coupled plasma atomic emission-spectrometry analysis confirmed the presence of cobalt in the epidermis and dermis. ${ }^{27}$

However, discrepancies have been found between studies. $\mathrm{TiO}_{2} \mathrm{NPs}$ were unable to penetrate intact or damaged mouse skin after topical application. In a cell-diffusion experiment, most $\mathrm{TiO}_{2} \mathrm{NPs}$ remained in the uppermost layers of the SC, and titanium was not detected in the receptor solution. ${ }^{43,44}$ These discrepancies might have been due to differences in skin models, analytical methods, and type of NPs and their physicochemical properties. In terms of particle size, $\mathrm{SiO}_{2}$ NPs with a diameter of $40 \mathrm{~nm}$ were able to be detected in the epidermis after topical application, but particles with a diameter of 750 or $1,500 \mathrm{~nm}$ were not observed. Another study using mouse skin with AD showed that $20 \mathrm{~nm} \mathrm{ZnO} \mathrm{NPs} \mathrm{(but}$ not $240 \mathrm{~nm} \mathrm{NPs}$ ) penetrated deeply into the epidermis. ${ }^{45,46}$

\section{Immune effects of metallic NPs upon skin exposure}

The applications of metallic NPs have become indispensable in everyday life. People can encounter metallic NPs in many products, such as cosmetics, medicines, electronics, and clothes. However, the increasing use of metallic NPs has raised concerns about their safety. In particular, their unique properties, large surface area, smallness, and high skin penetration might make them hazardous. ${ }^{47}$ Among the toxic effects of metallic NPs, the immune effect is of particular interest. Immune cells in the skin can recognize external substances. Metallic NPs that enter the skin cause immune responses, activating certain immune cells to proliferate and secrete. The host immunoresponse may lead to the onset or aggravation of sensitization reactions.
Skin sensitization induced by metallic NPs

Allergic and irritant dermatitis are the most common manifestations of skin sensitization by chemicals in humans. Metal allergy is a major cause of allergic and irritant dermatitis. Several metals, such as nickel, cobalt, chromium, palladium, and gold, are well-known skin allergens. Most are available as commercially engineered metallic NPs. ${ }^{48}$ Mechanical friction between these commercial metallic NPs and skin can cause abrasion, reduction in skin thickness, and skin irritation. More importantly, metallic ions released from metallic NPs play an important role in metal allergies. These metallic NPs are naturally generated from metal accessories, such as necklaces, earrings, and bracelets.

We are extemporaneously exposed to spontaneously generated metallic ions when we wear these accessories. Therefore, we should pay attention to skin sensitization by not only metallic NPs but also metallic ions. Nickel is prevalent in jewelry and can release $\mathrm{Ni}$ ions into the epidermis and cause allergic dermatitis. Because of their smallness and high surface:volume ratio, metallic NPs containing sensitizing metals trigger sensitization responses more easily than bulk materials with the same composition. ${ }^{49}$ Journeay and Goldman $^{50}$ reported allergic reactions to NiNPs, including facial flushing, nasal congestion, and asthma, which indicated that airborne particulates released by metallic NPs may also contribute to the sensitization process.

An in vivo sensitization test using rat-ear skin reported that topical exposure to $4 \mathrm{mg} / \mathrm{mL} \mathrm{TiO}_{2} \mathrm{NPs}_{\text {increased the }}$ titanium concentration in draining lymph-node cells and the stimulation index relative to the control group. However, no significant differences were seen in silver or $\mathrm{SiO}_{2} \mathrm{NP}$ groups relative to the control group. ${ }^{51}$ Moreover, a water-inoil emulsion formulation containing $10 \mathrm{wt} \% \mathrm{TiO}_{2} \mathrm{NPs}$ did not induce acute skin irritation. However, after subchronic exposure, skin inflammation characterized by parakeratosis and spongiosis was observed. These reports reflect that the onset of sensitization varies with the type of metallic NP and exposure duration. In addition, dose-dependent effects have also been taken into consideration. ${ }^{16}$ Auttachoat et al ${ }^{52}$ evaluated the sensitization potential of dermal exposure to $\mathrm{TiO}_{2} \mathrm{NPs}$ at levels of $1 \%, 2.5 \%, 5 \%$, and $10 \%$ (w:v). No significant effects were detected by local lymph-node assays or mouse ear-swelling tests. However, mice exposed to high concentrations (5\% and 10\%) had statistically significant results in an irritancy assay, which was a useful method for detecting the sensitization potential of chemicals. However, the low sensitization potential of many metallic NPs might be because the NPs do not penetrate healthy skin easily after 
topical application. Therefore, intradermal subcutaneous administration or tests on damaged skin are alternative routes for detecting the sensitization potential of metallic NPs. There was an investigation of topically applied ZnO NPs in a mouse model of AD. The results demonstrated that the application of ZnO NPs showed anti-inflammatory properties, diminishing the infiltration of $\mathrm{T}$ cells and suppressing the production of cytokines in sensitized mice. However, significantly elevated systemic IgE antibodies were detected in response to $\mathrm{ZnO} \mathrm{NP}$ application. This result provided new evidence of metallic NPs aggravating sensitization reactions. ${ }^{45}$

\section{Immunoresponses to transdermally applied metallic NPs}

Many studies have suggested that metallic NPs can trigger sensitization reactions. However, there is an urgent need to clarify the immunologic effects of skin exposure to metallic NPs, especially in how they aggravate allergies. Although many studies have been conducted to explore toxicity following skin exposure to metallic NPs, there is a lack of knowledge of immunologic mechanisms. In general, haptens are involved in immunoreactivity, but are not immunogenic. They have the potential to modify self-protein binding to obtain immunogenicity. ${ }^{53}$ In contrast to classic haptens, transition metals produce coordination complexes instead of stable covalent modifications with binding proteins. These coordination complexes are reversible and exchange allergenic metallic ions among different sites. ${ }^{54}$

When foreign substances enter the body, immune cells, such as antigen-presenting cells and leukocytes, recognize them and activate immunodefenses. In Smulders et al, increased Ti concentration was observed in draining lymphnode cells after topical application of $\mathrm{TiO}_{2} \mathrm{NPs}$, indicating that $\mathrm{TiO}_{2} \mathrm{NPs}$ penetrated the skin and were transferred to the lymph nodes. ${ }^{51}$ Human macrophages were found partially to dissolve $\mathrm{ZnO}$ NPs based on evaluations of $\mathrm{ZnO}$ NP counts with X-ray fluorescence and SEM. ${ }^{55}$ Therefore, one of the potential immunologic mechanisms after metallic NPs are topically applied might be that the NPs move to the lymph nodes, where they are engulfed by macrophages. On the other hand, metallic NPs activate adaptive immunoresponses. It has already been shown that $\mathrm{TiO}_{2}$ and $\mathrm{SiO}_{2}$ NPs can activate murine dendritic cells by upregulating costimulatory molecules. ${ }^{56}$ Metallic ions, such as Ni ions, were capable of activating metallic ion-specific $\mathrm{CD} 4^{+} \mathrm{T}$ cells in the lymph nodes, and IL17 was produced in response to metallic ions. In addition, the smaller the metallic NPs were, the stronger the immunoreaction was (Figure 1)..$^{57,58}$ On the basis of these studies, metallic NPs have been speculated to act as carriers to transport metallic ions into the lymph nodes for $\mathrm{CD} 4^{+} \mathrm{T}$ cell- and IL17-mediated immunoresponses. In the case of inflammatory skin diseases, such as $\mathrm{AD}$ and psoriasis, the exact immunoresponses and whether these responses can infect skin inflammation are not yet fully understood.

\section{Possible toxicity mechanisms of metallic NPs with skin cells}

Increasing skin exposure of metallic NPs from a variety of nanotechnology applications has raised concerns regarding potential adverse effects on human health. Of all possible entry routes, skin absorption may serve as the first portal for metallic NP exposure. As mentioned, transdermally applied metallic NPs can penetrate damaged or even intact skin. The high activity of metallic NPs has raised debate on their interactions with skin cells. Although some studies have been conducted to assess these interactions, their results were inconclusive (Table 2). ${ }^{15,59-75}$ The proposed mechanism is that metallic NPs generate oxidative stress, mitochondrial damage, and DNA damage, and accelerate the apoptosis of skin cells. ${ }^{10}$ The cellular mechanisms associated with metallic NPmediated toxicities are presented in the following sections.

\section{Membrane damage}

The cell membrane, which prevents extracellular materials from entering cells, is mainly composed of phospholipid bilayers. When metallic NPs enter the cell through the membrane, there is a risk of membrane disruption and cell toxicity. ${ }^{10}$ Indeed, membrane damage is one of the major concerns with regard to NP toxicity. The effects of $\mathrm{Fe}_{3} \mathrm{O}_{4}$ and $\mathrm{ZnO}$ NPs on mouse dermal fibroblast cells have been evaluated in vitro. SEM images provided information on the interactions of metallic NPs with the cell membrane. After exposure, a number of endocytic vesicles were detected on the cell membrane, and metallic NPs were visualized in either the cytoplasm or cytoplasmic vesicles, indicating that metallic NPs seemed to be phagocytosed by cells. In addition, cell morphology was observed by inverted phasecontrast microscopy, showing that NP-treated cells formed irregular shapes due to cytoplasmic shrinkage or were even completely necrotic at high NP concentrations. Meanwhile, cytoplasmic lactate dehydrogenase was detected in the extracellular fluid, indicating that the strong interactions between metallic NPs and the cell membrane led to morphological alterations and cell-membrane leakage. ${ }^{76,77}$ Studies have explored the potential mechanisms of NP-membrane interactions. NP attachment caused membrane rupture, increased 
Table 2 Risk evaluation of metal NPs in skin cells

\begin{tabular}{|c|c|c|c|c|c|}
\hline & $\begin{array}{l}\text { Size } \\
(\mathrm{nm})\end{array}$ & Concentration & $\begin{array}{l}\text { Cellular } \\
\text { model/ } \\
\text { organism }\end{array}$ & Impact & Reference \\
\hline $\mathrm{AgNPs}$ & 20 & $\mathrm{I}, \mathrm{I} 0 \mathrm{ng} / \mathrm{mL}$ & $\begin{array}{l}\text { Murine } \\
\text { fibroblasts }\end{array}$ & No significant cytotoxicity on cell viability & 59 \\
\hline AuNPs & 15 & $25,500 \mu \mathrm{g} / \mathrm{mL}$ & $\begin{array}{l}\text { Human dermal } \\
\text { fibroblasts }\end{array}$ & No morphological changes observed & 60 \\
\hline $\mathrm{TiO}_{2} \mathrm{NPs}$ & $10-60$ & $5 \%$ & $\begin{array}{l}\text { Hairless mouse } \\
\text { skin }\end{array}$ & $\begin{array}{l}\text { Changed production of MDA and reduced HYP expression } \\
\text { in skin samples }\end{array}$ & 61 \\
\hline SiNPs & 20 & $\begin{array}{l}500,1,000 \\
2,000 \mathrm{mg} / \mathrm{kg}\end{array}$ & Mouse skin & No systemic toxicity & 62 \\
\hline AgNPs & $75-90$ & $\mathrm{I}-100 \mu \mathrm{g} / \mathrm{mL}$ & $\begin{array}{l}\mathrm{HaCaT} \\
\text { keratinocytes }\end{array}$ & $\begin{array}{l}\text { Reduced cell viability; toxicity influenced by NP shape and } \\
\text { concentration }\end{array}$ & 63 \\
\hline $\mathrm{TiO}_{2} \mathrm{NPs}$ & $10 \pm 4$ & $1 \%$ & $\begin{array}{l}\text { Human dermal } \\
\text { fibroblasts }\end{array}$ & Initiated oxidative stress & 64 \\
\hline $\mathrm{TiO}_{2} \mathrm{NPs}$ & 50 & $\begin{array}{l}20,40,80 \\
160 \mu \mathrm{g} / \mathrm{mL}\end{array}$ & $\begin{array}{l}\text { Mouse } \\
\text { fibroblasts }\end{array}$ & $\begin{array}{l}\text { Initiated collagen deformation, inflammation, and protein } \\
\text { structural deformations }\end{array}$ & 65 \\
\hline $\begin{array}{l}\mathrm{TiO}_{2} \mathrm{NPs} \\
\mathrm{ZnO} \mathrm{NPs}\end{array}$ & $\begin{array}{l}21.5 \pm 0.6 \\
18.2 \pm 0.4\end{array}$ & $25 \%$ & $\begin{array}{l}\text { Hairless mouse } \\
\text { skin }\end{array}$ & $\begin{array}{l}\text { No histological changes seen in skin; elevated Ti detected } \\
\text { in mouse livers }\end{array}$ & 66 \\
\hline AgNPs & $15,30,55$ & $\begin{array}{l}20,30,40 \\
50 \mu g / m L\end{array}$ & $\begin{array}{l}\text { Human } \\
\text { neonatal skin } \\
\text { stromal cells }\end{array}$ & Caused apoptosis or necrosis & 67 \\
\hline $\mathrm{AgNPs}$ & $10,30,60$ & $1.0 \mathrm{mg} / \mathrm{mL}$ & $\begin{array}{l}\mathrm{HaCaT} \\
\text { keratinocytes }\end{array}$ & $\begin{array}{l}\text { Impact on cell viability and metabolism; downregulated } \\
\text { glycolysis and disrupted energy production common to } \\
\text { AgNPs; ROS mediated impact on metabolic pathways, such } \\
\text { as GSH synthesis, glutaminolysis, and the Krebs cycle }\end{array}$ & 68 \\
\hline $\mathrm{AgNPs}$ & $4.7,42$ & $\begin{array}{l}0.1-1.6 \mu \mathrm{g} / \mathrm{mL} \text { for } \\
4.7 \mathrm{~nm} ; 0.1-6.7 \mu \mathrm{g} / \mathrm{mL} \\
\text { for } 42 \mathrm{~nm}\end{array}$ & $\begin{array}{l}\text { Human dermal } \\
\text { fibroblasts }\end{array}$ & $\begin{array}{l}\text { Induced DNA-strand breaks in dose- and size-dependent } \\
\text { manner }\end{array}$ & 69 \\
\hline $\mathrm{SiO}_{2} \mathrm{NPs}$ & 15 & $2.5,5,10 \mu \mathrm{g} / \mathrm{mL}$ & $\begin{array}{l}\mathrm{HaCaT} \\
\text { keratinocytes }\end{array}$ & $\begin{array}{l}\text { Decreased DNMTI, DNMT3A, and MBD2 levels at mRNA } \\
\text { and protein levels, implying global epigenomic response }\end{array}$ & 70 \\
\hline $\mathrm{ZnO} N P s$ & $15.38 \pm 1.47$ & $10 \mu g / \mathrm{mL}$ & $\begin{array}{l}\text { Mouse } \\
\text { epidermal skin }\end{array}$ & $\begin{array}{l}\text { Led to cell death through autophagic vacuole accumulation } \\
\text { and mitochondrial damage via ROS induction }\end{array}$ & 71 \\
\hline $\mathrm{Fe}_{3} \mathrm{O}_{4} \mathrm{NPs}$ & 25 & $25,50,100 \mu \mathrm{g} / \mathrm{mL}$ & $\begin{array}{l}\text { Human skin } \\
\text { epithelial A43I } \\
\text { cells }\end{array}$ & $\begin{array}{l}\text { Depleted glutathione and induced ROS and lipid } \\
\text { peroxidation; significantly upregulated caspase } 3 \text { expression }\end{array}$ & 72 \\
\hline ZnO NPs & 30 & $\begin{array}{l}\text { I mg/day applied on } \\
\text { murine skin }\end{array}$ & $\begin{array}{l}\text { Murine facial } \\
\text { hair follicle } \\
\text { stem cells }\end{array}$ & $\begin{array}{l}\text { Caused obvious DNA damage and induced apoptosis; } \\
\text { perturbed genes associated with cell communication and } \\
\text { differentiation }\end{array}$ & 15 \\
\hline PtNPs & $4.8 \pm 11.7$ & $\begin{array}{l}25,50,100,200 \\
400 \mu g / m L\end{array}$ & $\begin{array}{l}\text { Human } \\
\text { foreskin } \\
\text { fibroblasts }\end{array}$ & $\begin{array}{l}\text { Inhibited DNA replication and affected secondary structure } \\
\text { of DNA; genotoxic stress activated p53 and subsequently } \\
\text { induced activation of p2I, leading to proliferating cell nuclear } \\
\text { antigen-mediated growth arrest in S phase and apoptosis }\end{array}$ & 73 \\
\hline $\mathrm{TiO}_{2} \mathrm{NPs}$ & $20-30$ & $0-1,000 \mu \mathrm{g} / \mathrm{mL}$ & $\begin{array}{l}\text { Human } \\
\text { fibroblast skin } \\
\text { cells }\end{array}$ & $\begin{array}{l}\text { Promoted cytotoxicity and oxidative damage; fatty-acid } \\
\text { composites could reduce toxicity }\end{array}$ & 74 \\
\hline $\begin{array}{l}\text { AgNPs } \\
\text { and } \\
\text { AuNPs }\end{array}$ & & $0.1, \mathrm{I}$, and $10 \mu \mathrm{g} / \mathrm{mL}$ & $\begin{array}{l}\text { Human } \\
\text { fibroblast skin } \\
\text { cells }\end{array}$ & $\begin{array}{l}\text { Decreased collagen, laminin production, and percentage } \\
\text { of cells expressing collagen receptor; may influence } \\
\text { fibroblast function by negatively modulating ECM deposition } \\
\text { and altering ECM-receptor expression, cytoskeletal } \\
\text { reorganization, and cell migration }\end{array}$ & 75 \\
\hline
\end{tabular}

Abbreviations: NPs, nanoparticles; ROS, reactive oxygen species.

cell-membrane permeability and influenced cell-membrane fluidity. ${ }^{78,79}$ Moreover, the combination of electrostatic attraction and hydrogen bonding between NPs and membranes was probably one of the reasons for membrane disruption and gelation. ${ }^{80}$

\section{Oxidative stress}

Reactive oxygen species (ROS) are generated by molecular oxygen during cellular oxidation. These oxygen species affect intracellular signaling pathways and lead to macromolecular damage, such as DNA disruption, protein 
denaturation, mitochondrial dysfunction, and membrane and cellular lipid breakdown. Although ROS occur naturally during cell metabolism, their overproduction can cause oxidative stress, which is often regarded as the main cause of NP cytotoxicity. ${ }^{81}$

Many reports have shown that metallic NPs can significantly enhance the formation of ROS in skin cells. ${ }^{8,82,83}$ Increased NO/ $\mathrm{NO}_{2}$ and decreased GPx in fibroblasts and $\mathrm{HaCaT}$ cells have been observed after exposure to metallic NPs, indicating that NPs caused inflammatory responses and metabolic changes. Additionally, NPs affected the gene expression of SOD and GPx. The presence of NPs increased the activities of SOD to promote the generation of hydrogen peroxide, which significantly decreased the protective molecule glutathione. Meanwhile, decreased GPx led to a reduction in toxic peroxides in cells. ${ }^{16,68,82}$ Similarly, an in vitro study showed that oxidative stress was the key cause of mitochondrial membrane damage, cell-cycle arrest, and DNA damage after mouse-skin fibroblast cells had been exposed to MoNPs. ${ }^{84}$ The secondary effect of ROS caused the activation of cell-death-mediated signaling via NFKB. NFKB is the transcription factor of apoptosis and leads to programmed cell death. ${ }^{85}$

Unlike other cells, skin cells are often exposed to UV-ray irradiation, and the photocatalytic activity of metallic NPs has raised concerns because of harmful ROS generation. UVB radiation is known to cause DNA oxidation through ROS generation. ${ }^{86}$ Interestingly, coexposure to UV rays and metallic NPs, such as $\mathrm{ZnO} / \mathrm{TiO}_{2} \mathrm{NPs}$, had a synergistic effect on phototoxicity by generating higher ROS levels and decreasing antioxidant-enzyme activity. Metallic NPs can overtake the antioxidant system by generating hydroxyl radicals to oxidize proteins and nitrogenize tyrosine residues of proteins in skin cells. ${ }^{87,88}$ Moreover, coexposure to UV rays and metallic NPs promoted the translocation of NPs into the nucleus, causing further oxidative stress and DNA and mitochondrial membrane damage, which led to cell-cycle arrest and apoptosis. ${ }^{89}$ However, $\mathrm{ZnO}$ and $\mathrm{TiO}_{2}$ NPs are commonly used in commercial sunscreen. It is possible that prolonged coexposure may cause persistent ROS generation and lead to continuous oxidative stress and inflammation.

\section{DNA damage}

Because metallic NPs are small and have special surface effects, they can interact with DNA molecules and cause direct and indirect genotoxic effects. DNA damage has been observed in primary human epidermal keratinocytes after exposure to ZnO NPs for 6 hours at concentrations of 8 and $14 \mathrm{~g} / \mathrm{mL}$. However, the internalization of ZnO NPs was investigated by SEM at only $14 \mathrm{~g} / \mathrm{mL}$, indicating that even if the NPs could not enter the nucleus, they still caused DNA damage during mitosis when the nuclear membrane was broken down. ${ }^{16,90}$ Siddiqui et al studied the genotoxic effects of MoNPs in mouse-skin fibroblast cells by comet assay and found the induction in percentage tail DNA and fold change in Olive tail moment and tail length, whereas the healthy chromosome should be spherical. ${ }^{84}$ ROS generation caused by NPs has a tremendous impact on mutagenicity, since DNA is a critical target of ROS. The genotoxicity of ROS has been confirmed by increases in the DNA-damage markers H2AX and 8-hydroxyguanosine after NP exposure, which was considered to be indirect genotoxicity by metallic NPs. ${ }^{89}$ ROS can oxidize the histones in nucleosomes and make free DNA more susceptible to damage. Hydroxyl radicals, which are oxygen-based ROS, can react with the deoxyribose-phosphate backbone and bases to damage the structure of DNA molecules. 8-Hydroxyguanosine was produced when hydroxyl radicals attacked guanosine and caused further oxidative damage. ${ }^{91}$ On the other hand, hydroxyl radicals abstract $\mathrm{H}$ atoms from DNA and lead to free modified sugars with broken DNA strands. The deoxyribose sugar of DNA can easily lose its free modified sugar and cause DNA-strand breakage. ${ }^{92}$ Furthermore, cell-cycle arrest in the $\mathrm{G}_{2} / \mathrm{M}$ phase has been observed after DNA damage. Afterward, the $\mathrm{G}_{2} / \mathrm{M}$ checkpoint prevented DNA damaged cells from entering a mitotic state for repair. ${ }^{93}$ DNA damage in skin cells may initiate the development of skin cancer or even genetic skin diseases.

\section{Epigenetic modulation}

Epigenetic processes are a series of biological changes in gene expression that do not alter the DNA sequence. These changes are stable and may persist after the external stimulus is removed, and they can even be passed down from one generation to the next. Epigenetic modifications regulate DNA replication and recombination by DNA methylation and hydroxymethylation, chromatin remodeling, histone modifications, and ncRNA-mediated events. ${ }^{94,95}$ Recently, studies identified the epigenetic variations of skin cells after exposure to metallic NPs. Nanosized $\mathrm{SiO}_{2}$ induced global genomic hypomethylation by decreasing the expression of methyltransferases DNMT1, DNMT3, and MBD2 in HaCaT cells. ${ }^{70}$ In the catalysis of DNMT, the cytosine residues at $\mathrm{CpG}$ dinucleotides are selected and methyl groups added at the $\mathrm{C} 5$ position. DNA methylation can cause gene inactivation, whereas hypomethylation activates certain genes. Furthermore, the expression of PARP1, a key gene in DNA repair, was dramatically decreased by $\mathrm{SiO}_{2} \mathrm{NP}$ exposure. An increase in the level of PARP1 methylation was observed, and decreased expression of PARP1 was rescued when DNMT1 
was inhibited or knocked down, indicating that PARP1 methylation after $\mathrm{SiO}_{2} \mathrm{NP}$ exposure may mediated by DNMT1. ${ }^{96}$

Chromatin is a complex that is mainly composed of DNA and histone. Posttranslational modifications of histones, such as methylation, acetylation, phosphorylation, SUMOylation, and ADP ribosylation, can greatly influence gene expression. In human epidermal keratinocytes, exposure to ZnO NPs causes hypermethylation of histone $\mathrm{H} 3 \mathrm{~K} 9$ and hypoacetylation of H4K5. These posttranslational modifications may change the signal for DNA-repair proteins and DNA accessibility to transcription factors. Modified histones and DNA methylation synergistically participate in transcription regulation. ${ }^{93,97}$ Given that epigenetic processes have gene-reprogramming ability via the modification of specific genes, such as $C A S P 3$, a pivotal terminal-shearing enzyme in cell apoptosis, epigenetic dysregulation may directly regulate cell proliferation, differentiation, and apoptosis. ${ }^{98}$ Additionally, epigenetic dysregulation is also considered to initiate cancers by activating silent oncogenes or inactivating tumor-suppressor genes. Therefore, it is possible that metallic NPs can cause skin tumors after skin exposure.

\section{Autophagy}

Autophagy is a nonapoptotic cell-death process in which cytoplasmic proteins or organelles are self-degraded by the formation of autophagosomes, which involves the microtubule-associated protein LC3, p62, and Beclin 1.99 Metallic NPs, such as $\mathrm{TiO}_{2}$ NPs, can also induce autophagy in primary human keratinocytes to maintain intracellular homeostasis and degrade insoluble NPs to protect cells against damage. However, autophagy does not stop damage and leads to cell death at high concentrations of $\mathrm{TiO}_{2} \mathrm{NPs}^{100}$ Meanwhile, ZnO NPs can lead to mitochondrial damage and autophagic cell death through the generation of ROS in normal skin cells. Autophagy is considered an important cytotoxic mechanism of metallic NPs. ${ }^{71}$ Moreover, $\mathrm{TiO}_{2}$ and $\mathrm{Fe}_{3} \mathrm{O}_{4}$ NPs have been shown to induce autophagy with increased lysosomal membrane permeabilization and overexpression of autophagy-related proteins in macrophages and monocytes. The autophagy process plays a protective role in preventing the inflammation induced by metallic NPs. The PI3K-Akt-mTOR signaling pathway is inhibited in the NP-mediated autophagy pathway (Figure 2). ${ }^{101,102}$

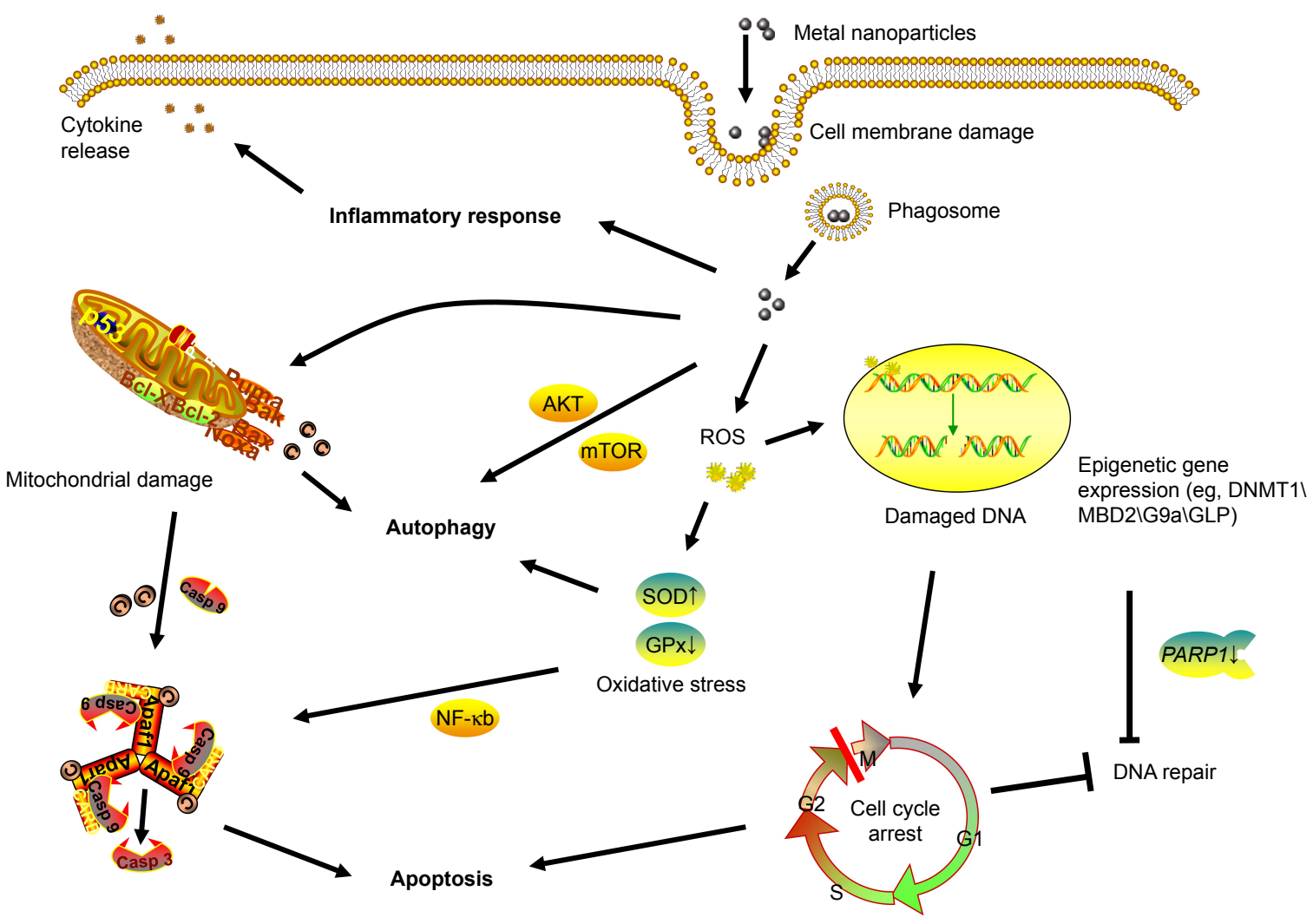

Figure 2 Possible toxic mechanisms of metal NPs in $\mathrm{HaCaT}$ cells.

Notes: Metal NPs induce ROS explosion intracellularly, and the accumulation of NPs might result in the following effects: cell-cycle arrest, which is associated with DNA damage and chromatin structure remodeling caused by oxidative stress $\left(G_{2} / M\right.$ cell-cycle arrest prevents DNA-damaged cells from entering mitosis to repair DNA and induce apoptosis); expression of epigenetic related genes, resulting in modifications of chromatin structure and alterations in gene expression; and mitochondrial damage and alteration of apoptosis and autophagy-related genes, which lead to autophagy and mitochondrial apoptosis.

Abbreviations: NPs, nanoparticles; ROS, reactive oxygen species. 


\section{Apoptosis}

Apoptosis is a complicated process of programmed cell death mediated by genes and causes self-destruction. Chromatin condensation, nuclear fragmentation, decreased mitochondrial activity, and apoptosis are observed in the $\mathrm{TiO}_{2}$ NP-treated human skin keratinocyte cell line HaCaT. Mohamed et al proposed an underlying mechanism for these changes. $\mathrm{TiO}_{2} \mathrm{NPs}$ caused the generation of ROS and in turn induced chromosomal aberrations and DNA damage, which were considered the essential factor in cell-cycle arrest. The cells underwent apoptosis during extensive cell arrest beyond their DNA-repair ability ${ }^{85,103}$ Similarly, studies have confirmed the internalization of ZnO NPs in keratinocytes by SEM and observed morphological changes, mitochondrial inhibition, DNA damage, cell-cycle arrest, and apoptosis, which indicated that ZnO NPs triggered apoptosis. ${ }^{16,89}$ The expression of proapoptotic genes $P U M A, B A X$, and NOXA significantly increased, whereas the expression of antiapoptotic BclxL decreased (Figure 2). The $B C L$ gene family is relevant to the mitochondrial apoptotic pathway, and Bax protein was a necessary gateway to mitochondrial dysfunction in the p53-related pathway. The authors proposed that $\mathrm{ZnO}$ NPs underwent mitochondria-dependent apoptosis through the p53-Bax pathway in skin cells. ${ }^{93}$ Additionally, in $\mathrm{ZnO}$ NP-treated human dermal fibroblasts, mitochondrial dysfunction with upregulation of p38 MAPK and p53 was observed. The activation of p38 MAPK and phosphorylation of p53 were detected at Ser33 and Ser 46 sites, suggesting that the apoptosis process in human dermal fibroblasts may be mediated through p53-p38 pathways. ${ }^{104}$ Another study showed different apoptosis pathways by metallic NPs: AgNP exposure led to not only the activation of $\mathrm{p} 38$ kinase but also increased caspase $3 / 7$ activity. ${ }^{105}$

Recently, hair follicles have been considered an important penetration route for metallic NP delivery through the skin. The impact of NPs on hair follicles has raised concerns. In newborn mice treated with continuous topical application of ZnO NPs for 7 days, elevated Bax and caspase 3 were detected in hair follicles, whereas Bcl2 decreased. An in vitro study of hair-follicle stem cells showed that ZnO NPs inhibited the proliferation and differentiation of cells and induced apoptosis. These results were confirmed by the dysregulated expression of proliferation-related genes, such as $J T B, P R K D 1$, and $F R K$, and differentiation related genes, such as PIK3R1, FRS2, SPEN, ACVR1B, and BMP4, by FGF signaling and BMP signaling. The observation of cell-cycle arrest, annexin V-PI analysis and increased caspase 3 further confirmed apoptosis execution. ${ }^{15}$

\section{Limitations and possible future research prospects}

Until now, our understanding of metallic NP toxicity has been insufficient to draw conclusions about the specific mechanisms of transdermally applied metallic NPs. Theoretically, the toxicity is based on NPs penetrating the SC. There is still debate as to whether metallic NPs can penetrate the skin barrier. Additionally, the interactions of metallic NPs and skin cells remain controversial. These inconsistent results may be caused by several factors, such as different types of NPs and physicochemical characterizations, varying experimental approaches, and various cellular or animal models. In-depth studies are needed on these influencing factors. Here, we note these limitations and provide some suggestions for further research.

First, detailed penetration mechanisms are imperative in future studies, as different penetration pathways may result in different toxicological reactions. Recent research has confirmed that metallic NPs can pass through the skin barrier through an intercellular route. ${ }^{17}$ The intracellular route (in which NPs penetrate keratinocytes) is recognized as one of the main skin-absorption routes. ${ }^{31}$ In addition, the follicular route has been considered, as NPs tend to accumulate in hair follicles. ${ }^{36}$ Few experimental data exist on detailed penetration mechanisms, especially for the latter two approaches. Future studies should include the relationships between these three main routes and their respective weights, as well as the qualitative and quantitative distribution of metallic NPs in the skin and the effects of metallic NPs on skin keratinocytes, fibroblasts, immune cells, and hair-follicle cells.

In experimental studies, penetration and toxicity are influenced largely by critical determinants, including physicochemical factors, such as type, size, shape, surface coating, charge, stability, and protein corona, experimental factors, such as concentration and exposure time, and formulation factors, such as dispersing vehicles. ${ }^{13,49,106}$ External factors, such as UV exposure, hyperthermia, and aggregation of NPs, should also be considered. ${ }^{18}$ These determinants may be the reason for the inconsistent conclusions in recent studies. Generally, the lipophilic nature of the vehicle, sphericity, and small dimensions favor more penetration, and toxicity is size- and concentration-dependent. However, our understanding of detailed mechanisms is still limited. This difficulty is due to an inability to design single-factor experiments that exclude other interfering factors. Moreover, the interaction between NPs and skin is a complex process that is affected by not only univariate parameters but also the interplay between 
individual parameters. It is difficult to duplicate "perfect" parameter control completely, as found in the human body.

Cells are embedded in an extracellular matrix (ECM), which consists of a network of fibers and proteins (ECMaffiliated proteins, collagens, proteoglycans, and glycoproteins). Recent studies have shown that physical features of the cell microenvironment can modulate a range of cell behavior, such as adhesion, differentiation, migration, proliferation, and survival. ${ }^{107}$ Most cells need substrates to function normally. The interaction between adhered cells and the ECM works together to constitute a stable dynamic system. On the other hand, intracellular components like cytoskeletal protein actin have the function of keeping cell motility, shape, and mechanical stability. The cytoskeletal protein actin attaches to the cell membrane and communicates biochemical signals with the ECM by transmembrane integrins. Any changes in the extracellular microenvironment can influence intracellular signaling and cell behavior. In this context, increased cell proliferation has been shown when cells were adhered to aligned collagen scaffolds compared to random ones. Substances like vitronectin enhanced cell differentiation by improving fibronectin absorption and fibril formation in the ECM. ${ }^{108}$ Adhered cells have also been subjected to a variety of stimuli, such as the stiffness of the ECM, polarity of charged substrates, and stresses from the motion of neighboring cells or surrounding fluid. ${ }^{109}$ Therefore, the cellular uptake of metallic NPs could also be regulated by the cell microenvironment, which would influence the efficiency and toxicity of NPs.

A growing number of researchers are concerned about the long-term effects of NPs and beginning to study the genotoxic effects of NP exposure. A few studies have accessed the epigenetic effects of NPs and even fewer have considered the effects of skin exposure. Recent studies have identified DNA and histone modifications by metallic NPs after skin exposure. However, the subsequent consequences and their direct causality remain unclear. In addition, there are many unsolved questions, such as whether noncoding RNAs are changed by metallic NPs and how these changes further affect biological processes. Can NPs cause skin tumors by epigenetic alterations? Future studies are needed to explore broader epigenetic mechanisms in pathological and genetic processes.

In regard to experimental models, the selection of biological samples and cell lines is of vital importance. The relative thickness of the SC varies greatly from species to species, as do the thickness of the epidermis and dermis and the number of skin layers. Generally, the penetration of pig skin is approximately four times deeper than human skin, whereas rat skin is up to nine times as permeable than human skin. ${ }^{21}$ The same metallic NPs can cause entirely different results, depending on various animal models and cell lines. Human skin should be used as the perfect skin model for in vitro experiments. Human skin samples are usually obtained through biopsy for penetration studies. Animal models, such as mice and pigs, are applied in in vivo studies because they are less expensive and more easily controlled than human studies. However, the results may vary among different animal models and can be affected by unpredicted factors. In addition, cell numbers in epidermal layers and absorption functions vary in different sites, even in humans. Animal type and sampling site should be considered parameters. ${ }^{17,110}$

There are various types of metallic NPs, but skin-toxicity studies focus mostly on several kinds that are most widely used in dermatology, such as AgNPs, AuNPs, ZnO NPs, and $\mathrm{TiO}_{2}$ NPs. Skin-toxicity research on metallic NPs like $\mathrm{Fe}_{3} \mathrm{O}_{4}$ NPs, PtNPs, NiNPs, and CoNPs is still in its initial stages. In regard to such NPs as $\mathrm{MnO}_{2}$ NPs and CuO NPs, these play important roles in industry and biomedical applications, but there are have been few studies on their skin toxicity. Inhalation of $\mathrm{MnO}_{2}$ NPs can cause central nervous system damage, such as Parkinson-like syndrome. In vitro study has shown that $\mathrm{MnO}_{2}$ NPs produced ROS and cell apoptosis and declined in mitochondrial membrane potential in human neuronal cells. ${ }^{111} \mathrm{CuO}$ NPs have been reported deposited within lysosomes and induced human umbilical vein endothelial cell death through a caspase-independent pathway. ${ }^{12}$ Future studies are needed to explore these metallic NPs, which may also have potential skin toxicity.

There is a lack of research on the barrier mechanisms of damaged skin, which may due to the difficulty of constructing an ideal model. Skin stripping by adhesive tape and drawing a point are commonly used methods to break the physical skin barrier. ${ }^{35,113}$ Inflammatory skin diseases, such as $\mathrm{AD}$ and psoriasis, are confirmed alterations of gene and protein expression related to epidermal differentiation and degeneration. These alterations affect the integrity of the SC, indicating that an animal model of inflammatory skin diseases can be utilized as an option. ${ }^{45}$ In regard to cell lines in vitro, cells derived from humans can better simulate the true condition in humans. Multiple primary cells, such as keratinocytes, fibroblasts, and hair-follicle stem cells, have been used to test the toxicity of metallic NPs, but culturing of barrier-damaged cells is extremely rare. ${ }^{15,114}$ Similarly to animal models, cell models of inflammatory skin diseases 
can be used. More cell experiments with barrier-damaged cells should be performed to evaluate the penetration and toxicity of metallic NPs comprehensively.

It has been concluded that metallic NPs can penetrate the skin barrier and reach deeper skin layers. ${ }^{25}$ Current techniques detecting the skin penetration of NPs are mostly based on qualitative analysis, such as TEM, SEM, and fluorescence microscopy. TEM is an imaging technique with high resolution for electron-dense materials in a small fraction of a sample. SEM provides high-quality images for a larger portion of a sample, but getting profile images of NP penetration and distribution is not easy. ${ }^{18,21}$ However, a great challenge for quantitative analysis is that metallic NPs that penetrate the skin are extremely small. Common quantitative approaches include methods of atomic absorption spectroscopy, inductively coupled plasma mass spectrometry, and inductively coupled plasma optical emission spectroscopy. Inevitably, the disadvantage of these methods is the detection of elements instead of NPs. An accurate qualitative and quantitative approach for better understanding of the distribution and toxicity of metallic NPs in the skin is urgently needed. ${ }^{18}$ In regard to toxicity studies, most studies have focused on cell viability, apoptosis, and molecular changes by multiple methods. However, these conclusions describe only experimental results in general, and specific signaling pathways in toxicology mechanisms need to be discovered in detail. In addition, toxicity investigations of metallic NPs on barrier-damaged skin and in long-term experiments and examinations of their related mechanisms are required in future.

\section{Conclusion}

Nanotechnology has made great contributions in dermatological and cosmetic fields. Widely used transdermal applications increase skin exposure to metallic NPs. Because skin is the largest organ in the human body, transdermal toxicity studies are essential for better understanding the toxic effects of metallic NPs. This review provided an overview of metallic NPs by summarizing penetration and toxicity mechanisms, proving that metallic NPs can penetrate the skin barrier and cause toxic side effects in skin cells; however, an understanding of in-depth mechanisms is required. This review also presented the limitations of current studies, which will provide new directions for further research.

\section{Acknowledgments}

This study was supported by the National Natural Science Foundation of China (51672122), the National Key Research and Development Program of China (2016YFC1102605 and 2016YFC1102603), and the President Foundation of Nanfang Hospital, Southern Medical University (2016B007).

\section{Disclosure}

The authors report no conflicts of interest in this work.

\section{References}

1. Shi H, Magaye R, Castranova V, Zhao J. Titanium dioxide nanoparticles: a review of current toxicological data. Part Fibre Toxicol. 2013; 10:15.

2. Issa B, Obaidat I, Albiss B, Haik Y. Magnetic nanoparticles: surface effects and properties related to biomedicine applications. Int $J \mathrm{Mol}$ Sci. 2013;14(11):21266-21305.

3. Su H, Wang Y, Gu Y, Bowman L, Zhao J, Ding M. Potential applications and human biosafety of nanomaterials used in nanomedicine. J Appl Toxicol. 2018;38(1):3-24.

4. Vance ME, Kuiken T, Vejerano EP, et al. Nanotechnology in the real world: redeveloping the nanomaterial consumer products inventory. Beilstein J Nanotechnol. 2015;6:1769-1780.

5. Wang SQ, Tooley IR. Photoprotection in the era of nanotechnology. Semin Cutan Med Surg. 2011;30(4):210-213.

6. Khan SU, Saleh TA, Wahab A, et al. Nanosilver: new ageless and versatile biomedical therapeutic scaffold. Int J Nanomedicine. 2018;13: 733-762.

7. Nafisi S, Schäfer-Korting M, Maibach HI. Perspectives on percutaneous penetration: silica nanoparticles. Nanotoxicology. 2015;9(5): 643-657.

8. Alili L, Chapiro S, Marten GU, Schmidt AM, Zanger K, Brenneisen P. Effect of $\mathrm{Fe}_{3} \mathrm{O}_{4}$ nanoparticles on skin tumor cells and dermal fibroblasts. Biomed Res Int. 2015;2015:530957.

9. Vimbela G, Ngo SM, Fraze C, Yang L, Stout DA. Antibacterial properties and toxicity from metallic nanomaterials. Int J Nanomedicine. 2017;12:3941-3965.

10. Niska K, Zielinska E, Radomski MW, Inkielewicz-Stepniak I. Metal nanoparticles in dermatology and cosmetology: Interactions with human skin cells. Chem Biol Interact. Epub 2017 Jun 19.

11. Rancan F, Gao Q, Graf C, et al. Skin penetration and cellular uptake of amorphous silica nanoparticles with variable size, surface functionalization, and colloidal stability. ACS Nano. 2012;6(8):6829-6842.

12. Brandner JM, Zorn-Kruppa M, Yoshida T, Moll I, Beck LA, de Benedetto A. Epidermal tight junctions in health and disease. Tissue Barriers. 2015;3(1-2):e974451.

13. Tak YK, Pal S, Naoghare PK, Rangasamy S, Song JM. Shape-dependent skin penetration of silver nanoparticles: does it really matter? Sci Rep. 2015;5:16908.

14. Sufian MM, Khattak JZ, Yousaf S, Rana MS. Safety issues associated with the use of nanoparticles in human body. Photodiagnosis Photodyn Ther. 2017;19:67-72.

15. Ge W, Zhao Y, Lai F-N, et al. Cutaneous applied nano-ZnO reduce the ability of hair follicle stem cells to differentiate. Nanotoxicology. 2017;11(4):465-474.

16. Sharma V, Singh SK, Anderson D, Tobin DJ, Dhawan A. Zinc oxide nanoparticle induced genotoxicity in primary human epidermal keratinocytes. J Nanosci Nanotechnol. 2011;11(5):3782-3788.

17. Filon FL, Mauro M, Adami G, Bovenzi M, Crosera M. Nanoparticles skin absorption: new aspects for a safety profile evaluation. Regul Toxicol Pharmacol. 2015;72(2):310-322.

18. Labouta HI, Schneider M. Interaction of inorganic nanoparticles with the skin barrier: current status and critical review. Nanomedicine. 2013; 9(1):39-54.

19. Lin LL, Grice JE, Butler MK, et al. Time-correlated single photon counting for simultaneous monitoring of zinc oxide nanoparticles and $\mathrm{NAD}(\mathrm{P}) \mathrm{H}$ in intact and barrier-disrupted volunteer skin. Pharm Res. 2011;28(11):2920-2930. 
20. Adachi K, Yamada N, Yoshida Y, Yamamoto O. Subchronic exposure of titanium dioxide nanoparticles to hairless rat skin. Exp Dermatol. 2013;22(4):278-283.

21. Gulson B, Mccall MJ, Bowman DM, Pinheiro T. A review of critical factors for assessing the dermal absorption of metal oxide nanoparticles from sunscreens applied to humans, and a research strategy to address current deficiencies. Arch Toxicol. 2015;89(11):1909-1930.

22. Filipe $P$, Silva JN, Silva R, et al. Stratum corneum is an effective barrier to $\mathrm{TiO}_{2}$ and $\mathrm{ZnO}$ nanoparticle percutaneous absorption. Skin Pharmacol Physiol. 2009;22(5):266-275.

23. Labouta HI, Hampel M, Thude S, Reutlinger K, Kostka KH, Schneider M. Depth profiling of gold nanoparticles and characterization of point spread functions in reconstructed and human skin using multiphoton microscopy. J Biophotonics. 2012;5(1):85-96.

24. Zhu Y, Choe CS, Ahlberg S, et al. Penetration of silver nanoparticles into porcine skin ex vivo using fluorescence lifetime imaging microscopy, Raman microscopy, and surface-enhanced Raman scattering microscopy. J Biomed Opt. 2015;20(5):051006.

25. George R, Merten S, Wang TT, Kennedy P, Maitz P. In vivo analysis of dermal and systemic absorption of silver nanoparticles through healthy human skin. Australas J Dermatol. 2014;55(3):185-190.

26. Labouta HI, el-Khordagui LK, Kraus T, Schneider M. Mechanism and determinants of nanoparticle penetration through human skin. Nanoscale. 2011;3(12):4989-4999.

27. Filon FL, Crosera M, Timeus E, et al. Human skin penetration of cobalt nanoparticles through intact and damaged skin. Toxicol In Vitro. 2013;27(1):121-127.

28. Crosera M, Adami G, Mauro M, Bovenzi M, Baracchini E, Larese Filon F. In vitro dermal penetration of nickel nanoparticles. Chemosphere. 2016;145:301-306.

29. Fernandes R, Smyth NR, Muskens OL, et al. Interactions of skin with gold nanoparticles of different surface charge, shape, and functionality. Small. 2015;11(6):713-721.

30. Musazzi UM, Santini B, Selmin F, et al. Impact of semi-solid formulations on skin penetration of iron oxide nanoparticles. J Nanobiotechnology. 2017;15(1):14.

31. Reis CP, Rijo P, Pereira P, Antunes AF. Nanosystems for skin delivery: from drugs to cosmetics. Curr Drug Metab. 2017;18(5):412-425.

32. Lee SE, Choi KJ, Menon GK, et al. Penetration Pathways induced by low-frequency sonophoresis with physical and chemical enhancers: iron oxide nanoparticles versus lanthanum nitrates. J Invest Dermatol. 2010; 130(4):1063-1072.

33. Zhang L, Yu W, Colvin V, Monteiro-Riviere N. Biological interactions of quantum dot nanoparticles in skin and in human epidermal keratinocytes. Toxicol Appl Pharmacol. 2008;228(2):200-211.

34. Mathes C, Brandner JM, Laue M, et al. Tight junctions form a barrier in porcine hair follicles. Eur J Cell Biol. 2016;95(2):89-99.

35. Senzui M, Tamura T, Miura K, Ikarashi Y, Watanabe Y, Fujii M. Study on penetration of titanium dioxide $\left(\mathrm{TiO}_{2}\right)$ nanoparticles into intact and damaged skin in vitro. J Toxicol Sci. 2010;35(1):107-113.

36. Mahmoud NN, Alkilany AM, Dietrich D, Karst U, al-Bakri AG, Khalil EA. Preferential accumulation of gold nanorods into human skin hair follicles: effect of nanoparticle surface chemistry. J Colloid Interface Sci. 2017;503:95-102.

37. Feldmann RJ, Maibach HI. Regional variation in percutaneous penetration of ${ }^{14} \mathrm{C}$ cortisol in man. J Invest Dermatol. 1967;48(2):181-183.

38. Teichmann A, Otberg N, Jacobi U, Sterry W, Lademann J. Follicular penetration: development of a method to block the follicles selectively against the penetration of topically applied substances. Skin Pharmacol Physiol. 2006;19(4):216-223.

39. Jatana S, Delouise LA. Understanding engineered nanomaterial skin interactions and the modulatory effects of ultraviolet radiation skin exposure. Wiley Interdiscip Rev Nanomed Nanobiotechnol. 2014;6(1): 61-79.

40. Lin YK, Yang SH, Chen CC, Kao HC, Fang JY. Using imiquimodinduced psoriasis-like skin as a model to measure the skin penetration of anti-psoriatic drugs. PLoS One. 2015;10(9):e0137890.
41. Vogt A, Wischke C, Neffe AT, Ma N, Alexiev U, Lendlein A. Nanocarriers for drug delivery into and through the skin: do existing technologies match clinical challenges? J Control Release. 2016;242:3-15.

42. Kubo A, Nagao K, Amagai M. Epidermal barrier dysfunction and cutaneous sensitization in atopic diseases. J Clin Invest. 2012;122(2): $440-447$.

43. Xie G, Lu W, Lu D. Penetration of titanium dioxide nanoparticles through slightly damaged skin in vitro and in vivo. $J$ Appl Biomater Funct Mater. 2015;13(4):e356-e361.

44. Miquel-Jeanjean C, Crépel F, Raufast V, et al. Penetration study of formulated nanosized titanium dioxide in models of damaged and sun-irradiated skins. Photochem Photobiol. 2012;88(6):1513-1521.

45. Ilves M, Palomäki J, Vippola M, et al. Topically applied ZnO nanoparticles suppress allergen induced skin inflammation but induce vigorous IgE production in the atopic dermatitis mouse model. Part Fibre Toxicol. 2014;11:38.

46. Vogt A, Combadiere B, Hadam S, et al. $40 \mathrm{~nm}$, but not 750 or $1,500 \mathrm{~nm}$, nanoparticles enter epidermal CD1a+ cells after transcutaneous application on human skin. J Invest Dermatol. 2006;126(6): 1316-1322.

47. Kunzmann A, Andersson B, Thurnherr T, Krug H, Scheynius A, Fadeel B. Toxicology of engineered nanomaterials: focus on biocompatibility, biodistribution and biodegradation. Biochim Biophys Acta. 1810;2011(3):361-373.

48. Thyssen JP, Menné T. Metal allergy: a review on exposures, penetration, genetics, prevalence, and clinical implications. Chem Res Toxicol. 2010;23(2):309-318.

49. Filon FL, Bello D, Cherrie JW, Sleeuwenhoek A, Spaan S, Brouwer DH. Occupational dermal exposure to nanoparticles and nano-enabled products - part I: factors affecting skin absorption. Int J Hyg Environ Health. 2016;219(6):536-544.

50. Journeay WS, Goldman RH. Occupational handling of nickel nanoparticles: a case report. Am J Ind Med. 2014;57(9):1073-1076.

51. Smulders S, Golanski L, Smolders E, Vanoirbeek J, Hoet PH. Nano$\mathrm{TiO}_{2}$ modulates the dermal sensitization potency of dinitrochlorobenzene after topical exposure. Br J Dermatol. 2015;172(2):392-399.

52. Auttachoat W, McLoughlin CE, White KL, Smith MJ. Route-dependent systemic and local immune effects following exposure to solutions prepared from titanium dioxide nanoparticles. J Immunotoxicol. 2014; 11(3):273-282.

53. Karlberg AT, Börje A, Johansen JD, et al. Activation of non-sensitizing or low-sensitizing fragrance substances into potent sensitizers-prehaptens and prohaptens. Contact Dermatitis. 2013;69(6):323-334.

54. Fage SW, Muris J, Jakobsen SS, Thyssen JP. Titanium: a review on exposure, release, penetration, allergy, epidemiology, and clinical reactivity. Contact Dermatitis. 2016;74(6):323-345.

55. James SA, Feltis BN, de Jonge MD, et al. Quantification of ZnO nanoparticle uptake, distribution, and dissolution within individual human macrophages. ACS Nano. 2013;7(12):10621-10635.

56. Winter M, Beer HD, Hornung V, Krämer U, Schins RP, Förster I. Activation of the inflammasome by amorphous silica and $\mathrm{TiO}_{2}$ nanoparticles in murine dendritic cells. Nanotoxicology. 2011;5(3):326-340.

57. Yoshioka Y, Kuroda E, Hirai T, Tsutsumi Y, Ishii KJ. Allergic responses induced by the immunomodulatory effects of nanomaterials upon skin exposure. Front Immunol. 2017;8(10):169.

58. Thierse HJ, Gamerdinger K, Junkes C, Guerreiro N, Weltzien HU. T cell receptor (TCR) interaction with haptens: metal ions as non-classical haptens. Toxicology. 2005;209(2):101-107.

59. Salvioni L, Galbiati E, Collico V, et al. Negatively charged silver nanoparticles with potent antibacterial activity and reduced toxicity for pharmaceutical preparations. Int J Nanomedicine. 2017;12:2517-2530.

60. Penders J, Stolzoff M, Hickey DJ, Andersson M, Webster TJ. Shapedependent antibacterial effects of non-cytotoxic gold nanoparticles. Int J Nanomedicine. 2017;12:2457-2468.

61. Wu J, Liu W, Xue C, et al. Toxicity and penetration of $\mathrm{TiO}_{2}$ nanoparticles in hairless mice and porcine skin after subchronic dermal exposure. Toxicol Lett. 2009;191(1):1-8. 
62. Ryu HJ, Seong NW, So BJ, et al. Evaluation of silica nanoparticle toxicity after topical exposure for 90 days. Int J Nanomedicine. 2014; 9 Suppl 2:127-136.

63. Holmes AM, Lim J, Studier H, Roberts MS. Varying the morphology of silver nanoparticles results in differential toxicity against micro-organisms, HaCaT keratinocytes and affects skin deposition. Nanotoxicology. 2016;10(10):1503-1514.

64. Nica I, Stan M, Popa M, et al. Interaction of new-developed $\mathrm{TiO}_{2}-$ based photocatalytic nanoparticles with pathogenic microorganisms and human dermal and pulmonary fibroblasts. Int J Mol Sci. 2017;18(2):249

65. Kuku G, Culha M. Investigating the origins of toxic response in $\mathrm{TiO}_{2}$ nanoparticle-treated cells. Nanomaterials (Basel). 2017;7(4):E83.

66. Osmond-Mcleod MJ, Oytam Y, Rowe A, et al. Long-term exposure to commercially available sunscreens containing nanoparticles of $\mathrm{TiO}_{2}$ and $\mathrm{ZnO}$ revealed no biological impact in a hairless mouse model. Part Fibre Toxicol. 2015;13(1):44.

67. Alsalhi MS, Devanesan S, Alfuraydi AA, et al. Green synthesis of silver nanoparticles using Pimpinella anisum seeds: antimicrobial activity and cytotoxicity on human neonatal skin stromal cells and colon cancer cells. Int J Nanomedicine. 2016;11:4439-4449.

68. Carrola J, Bastos V, Jarak I, et al. Metabolomics of silver nanoparticles toxicity in HaCaT cells: structure-activity relationships and role of ionic silver and oxidative stress. Nanotoxicology. 2016;10(8):1105-1117.

69. Avalos A, Haza AI, Morales P. Manufactured silver nanoparticles of different sizes induced DNA strand breaks and oxidative DNA damage in hepatoma and leukaemia cells and in dermal and pulmonary fibroblasts. Folia Biol (Praha). 2015;61(1):33-42.

70. Gong $\mathrm{C}$, Tao G, Yang L, et al. $\mathrm{SiO}$, nanoparticles induce global genomic hypomethylation in HaCaT cells. Biochem Biophys Res Commun. 2010;397(3):397-400.

71. Yu KN, Yoon TJ, Minai-Tehrani A, et al. Zinc oxide nanoparticle induced autophagic cell death and mitochondrial damage via reactive oxygen species generation. Toxicol In Vitro. 2013;27(4):1187-1195.

72. Ahamed M, Alhadlaq HA, Alam J, Khan MA, Ali D, Alarafi S. Iron oxide nanoparticle-induced oxidative stress and genotoxicity in human skin epithelial and lung epithelial cell lines. Curr Pharm Des. 2013;19(37):6681-6690.

73. Nejdl L, Kudr J, Moulick A, et al. Platinum nanoparticles induce damage to DNA and inhibit DNA replication. PLoS One. 2017;12(7):e0180798.

74. Chang J, Lee CW, Alsulimani HH, et al. Role of fatty acid composites in the toxicity of titanium dioxide nanoparticles used in cosmetic products. J Toxicol Sci. 2016;41(4):533-542.

75. Vieira LF, Lins MP, Viana IM, dos Santos JE, Smaniotto S, Reis MD. Metallic nanoparticles reduce the migration of human fibroblasts in vitro. Nanoscale Res Lett. 2017;12(1):200.

76. Seker S, Elçin AE, Yumak T, Sınağ A, Elçin YM. In vitro cytotoxicity of hydrothermally synthesized $\mathrm{ZnO}$ nanoparticles on human periodontal ligament fibroblast and mouse dermal fibroblast cells. Toxicol in Vitro. 2014;28(8):1349-1358.

77. Güngüneş $C D$, Şeker S, Elçin AE, Elçin YM. A comparative study on the in vitro cytotoxic responses of two mammalian cell types to fullerenes, carbon nanotubes and iron oxide nanoparticles. Drug Chem Toxicol. 2017;40(2):215-227.

78. Wei X, Jiang W, Yu J, Ding L, Hu J, Jiang G. Effects of $\mathrm{SiO}_{2}$ nanoparticles on phospholipid membrane integrity and fluidity. $J$ Hazard Mater. 2015;287:217-224.

79. de Planque MR, Aghdaei S, Roose T, Morgan H. Electrophysiological characterization of membrane disruption by nanoparticles. ACS Nano. 2011;5(5):3599-3606.

80. Wei X, Yu J, Ding L, Hu J, Jiang W. Effect of oxide nanoparticles on the morphology and fluidity of phospholipid membranes and the role of hydrogen bonds. J Environ Sci (China). 2017;57:221-230.

81. Ali A, Suhail M, Mathew S, et al. Nanomaterial induced immune responses and cytotoxicity. J Nanosci Nanotechnol. 2016;16(1): 40-57.
82. Kinoda J, Ishihara M, Hattori H, Nakamura S, Fukuda K, Yokoe H. Cytotoxicity of silver nanoparticle and chitin-nanofiber sheet composites caused by oxidative stress. Nanomaterials (Basel). 2016;6(10):E189.

83. Harvanova MP, Jiravova J, Malohlava J, Tomankova KB, Jirova D, Kolarova H. Raman imaging of cellular uptake and studies of silver nanoparticles effect in BJ human fibroblasts cell lines. Int J Pharm. 2017;528(1-2):280-286.

84. Siddiqui MA, Saquib Q, Ahamed M, et al. Molybdenum nanoparticlesinduced cytotoxicity, oxidative stress, G2/M arrest, and DNA damage in mouse skin fibroblast cells (L929). Colloids Surf B Biointerfaces. 2015;125:73-81.

85. Mohamed MS, Torabi A, Paulose M, Kumar DS, Varghese OK. Anodically grown titania nanotube induced cytotoxicity has genotoxic origins. Sci Rep. 2017;7:41844.

86. Narendhirakannan RT, Hannah MA. Oxidative stress and skin cancer: an overview. Indian J Clin Biochem. 2013;28(2):110-115.

87. Tu M, Huang Y, Li HL, Gao ZH. The stress caused by nitrite with titanium dioxide nanoparticles under UVA irradiation in human keratinocyte cell. Toxicology. 2012;299(1):60-68.

88. Tyagi N, Srivastava SK, Arora S, et al. Comparative analysis of the relative potential of silver, zinc-oxide and titanium-dioxide nanoparticles against UVB-induced DNA damage for the prevention of skin carcinogenesis. Cancer Lett. 2016;383(1):53-61.

89. Pal A, Alam S, Mittal S, et al. UVB irradiation-enhanced zinc oxide nanoparticles-induced DNA damage and cell death in mouse skin. Mutat Res Genet Toxicol Environ Mutagen. 2016;807:15-24.

90. Magdolenova Z, Collins A, Kumar A, Dhawan A, Stone V, Dusinska M. Mechanisms of genotoxicity: a review of in vitro and in vivo studies with engineered nanoparticles. Nanotoxicology. 2014;8(3):233-278.

91. Zhu X, Hondroulis E, Liu W, Li CZ. Biosensing approaches for rapid genotoxicity and cytotoxicity assays upon nanomaterial exposure. Small. 2013;9(9-10):1821-1830.

92. Dissanayake N, Current K, Obare S. Mutagenic effects of iron oxide nanoparticles on biological cells. Int J Mol Sci. 2015;16(10): 23482-23516.

93. Gao F, Ma N, Zhou H, et al. Zinc oxide nanoparticles-induced epigenetic change and G2/M arrest are associated with apoptosis in human epidermal keratinocytes. Int J Nanomedicine. 2016;11:3859-3874.

94. Costa PM, Fadeel B. Emerging systems biology approaches in nanotoxicology: towards a mechanism-based understanding of nanomaterial hazard and risk. Toxicol Appl Pharmacol. 2016;299:101-111.

95. Sierra MI, Valdés A, Fernandez AF, Torrecillas R, Fraga MF. The effect of exposure to nanoparticles and nanomaterials on the mammalian epigenome. Int J Nanomedicine. 2016;11:6297-6306.

96. Gong C, Tao G, Yang L, et al. Methylation of PARP-1 promoter involved in the regulation of nano- $\mathrm{SiO}_{2}$-induced decrease of PARP-1 mRNA expression. Toxicol Lett. 2012;209(3):264-269.

97. Shyamasundar S, Ng CT, Yung LY, Dheen ST, Bay BH. Epigenetic mechanisms in nanomaterial-induced toxicity. Epigenomics. 2015;7(3): 395-411.

98. Xu B, Mao Z, Ji X, et al. miR-98 and its host gene Huwe1 target caspase-3 in silica nanoparticles-treated male germ cells. Sci Rep. 2015;5: 12938

99. Ou L, Song B, Liang H, et al. Toxicity of graphene-family nanoparticles: a general review of the origins and mechanisms. Part Fibre Toxicol. 2016;13(1):57.

100. Zhao Y, Howe JL, Yu Z, et al. Exposure to titanium dioxide nanoparticles induces autophagy in primary human keratinocytes. Small. 2013;9(3):387-392.

101. Yu Q, Wang H, Peng Q, Li Y, Liu Z, Li M. Different toxicity of anatase and rutile $\mathrm{TiO}_{2}$ nanoparticles on macrophages: involvement of difference in affinity to proteins and phospholipids. J Hazard Mater. 2017;335:125-134.

102. Wu Q, Jin R, Feng $\mathrm{T}$, et al. Iron oxide nanoparticles and induced autophagy in human monocytes. Int J Nanomedicine. 2017;12: 3993-4005. 
103. Gao X, Wang Y, Peng S, et al. Comparative toxicities of bismuth oxybromide and titanium dioxide exposure on human skin keratinocyte cells. Chemosphere. 2015;135:83-93.

104. Meyer K, Rajanahalli P, Ahamed M, Rowe JJ, Hong Y. ZnO nanoparticles induce apoptosis in human dermal fibroblasts via p53 and p38 pathways. Toxicol In Vitro. 2011;25(8):1721-1726.

105. Szmyd R, Goralczyk AG, Skalniak L, et al. Effect of silver nanoparticles on human primary keratinocytes. Biol Chem. 2013;394(1):113-123.

106. Leite-Silva VR, le Lamer M, Sanchez WY, et al. The effect of formulation on the penetration of coated and uncoated zinc oxide nanoparticles into the viable epidermis of human skin in vivo. Eur $J$ Pharm Biopharm. 2013;84(2):297-308.

107. Burgstaller G, Sengupta A, Vierkotten S, et al. Distinct niches within the extracellular matrix dictate fibroblast function in (cell free) 3D lung tissue cultures. Am J Physiol Lung Cell Mol Physiol. 2018;314(5): L708-L723.

108. Cantini M, Gomide K, Moulisova V, González-García C, SalmerónSánchez M. Vitronectin as a micromanager of cell response in materialdriven fibronectin nanonetworks. Adv Biosyst. 2017;1(9):1700047.
109. Denning D, Roos WH. Elucidating the molecular mechanisms underlying cellular response to biophysical cues using synthetic biology approaches. Cell Adh Migr. 2016;10(5):540-553.

110. Sadrieh N, Wokovich AM, Gopee NV, et al. Lack of significant dermal penetration of titanium dioxide from sunscreen formulations containing nano- and submicron-size $\mathrm{TiO}_{2}$ particles. Toxicol Sci. 2010;115(1): $156-166$

111. Alarifi S, Ali D, Alkahtani S. Oxidative stress-induced DNA damage by manganese dioxide nanoparticles in human neuronal cells. Biomed Res Int. 2017;2017:5478790.

112. Zhang J, Zou Z, Wang B, et al. Lysosomal deposition of copper oxide nanoparticles triggers HUVEC cells death. Biomaterials. 2018;161: 228-239.

113. Filon FL, Crosera M, Adami G, Bovenzi M, Rossi F, Maina G. Human skin penetration of gold nanoparticles through intact and damaged skin. Nanotoxicology. 2011;5(4):493-501.

114. Galandáková A, Franková J, Ambrožová N, et al. Effects of silver nanoparticles on human dermal fibroblasts and epidermal keratinocytes. Hum Exp Toxicol. 2016;35(9):946-957.
International Journal of Nanomedicine

\section{Publish your work in this journal}

The International Journal of Nanomedicine is an international, peerreviewed journal focusing on the application of nanotechnology in diagnostics, therapeutics, and drug delivery systems throughout the biomedical field. This journal is indexed on PubMed Central, MedLine, CAS, SciSearch $\AA$, Current Contents ${ }^{\circledR} /$ Clinical Medicine,

\section{Dovepress}

Journal Citation Reports/Science Edition, EMBase, Scopus and the Elsevier Bibliographic databases. The manuscript management system is completely online and includes a very quick and fair peer-review system, which is all easy to use. Visit http://www.dovepress.com/ testimonials.php to read real quotes from published authors. 